\title{
Estudo experimental da influência das dimensões dos grânulos de hidroxiapatita na integração óssea
}

\author{
Influence od dimensions of hydroxiapatite granules upon bone integration: an experimental study
}

\author{
Adriana Santos Barone Moreira ${ }^{1}$, Monica Tempeste Pastorell ${ }^{2}$, \\ Luiz Henrique Fonseca Damasceno ${ }^{3}$, Helton luiz Aparecido Defino ${ }^{4}$
}

\section{RESUMO}

Foi realizado estudo experimental em ratos Wistar para a avaliação da integração óssea dos grânulos de hidroxiapatita de diferentes tamanhos $(212 \mu, 500 \mu$ e $1000 \mu)$. Os animais foram divididos em três grupos experimentais (dois grupos com 15 animais e um grupo com 25 animais) e foram sacrificados com 30, 90 e 180 dias após a implantação da hidroxiapatita, que foi utilizada para o preenchimento de falha óssea produzida no fêmur. Dez animais formaram o grupo controle, cujo falha produzida no fêmur não foi preenchida com a HA. Os animais foram avaliados por meio de estudo radiológico e histológico, utilizando-se microscopia de luz para a avaliação da interface entre o tecido ósseo e a hidroxiapatita.

Foi observado que os grânulos de hidroxiapatita utilizados para o preenchimento da falha óssea foram biocompatíveis e que a restauração da falha óssea ocorreu mais rapidamente nas falhas ósseas preenchidas com a HA que apresentava grânulos de menor diâmetro $(212 \mu)$.

Descritores: Osseointegração; Hidroxiapatita; Ratos wistar.

\section{INTRODUÇÃO}

A procura de substitutos dos enxertos ósseos, capazes de promover a osteointegração, o restabelecimento, a remodelação e o reforço das estruturas ósseas, tem estimulado a pesquisa de materiais sintéticos capazes de substituir os enxertos ósseos ${ }^{(1,6)}$. Os enxertos ósseos apresentam eficiência mecânica e biológica, mas as limitações relacionadas à sua utilização estão relacionadas com as complicações do local de sua retirada, e com a sua escassez nos pacientes submetidos a múltiplos procedimentos ${ }^{(2,11,15)}$.

A cerâmica de hidroxiapatita tem sido estudada por tratarse de uma substância bioativa não tóxica, que provoca pouca

\section{SUMMARY}

This trial was performed in Wistar rats to evaluate bone integration of hydroxyapatite (HA) granules of different sizes $(212 \mu \mathrm{m}$, $500 \mu \mathrm{m}$, and $1000 \mu \mathrm{m})$. The animals were divided into three experimental groups, that is, two groups of 15 animals and one group of 25 animals, which were killed, respectively, 30, 90 and 180 days after the implantation of the hydroxyapatite employed to fill the bone defects produced in the rats' femurs. Additionally, a control group included ten rats whose induced femur defects were not filled with $\mathrm{HA}$. All animals were radiologically and histologically examined by light microscopy, in order to evaluate the bone tissue / hydroxyapatite interface.

It was seen that the hydroxyapatite granules employed to fill the bone defects were biocompatible and that the bone defect was restored faster in the bone defects filled with HA whose granules had smaller diameters (212 $\mu \mathrm{m})$.

Key words: Osseointegration; Durapatite; Rats, Wistar.

\section{INTRODUCTION}

The search for bone graft substitutes capable of promoting osteointegration, recovery, remodeling and restrengthening of bone structures has stimulated the search for synthetic materials capable of replacing bone grafts ${ }^{(1,6)}$. Bone grafts are mechanically and biologically effective, although the limitations related to their use are associated to the complications found at the site of their removal and to the scarcity of their presences in patients who underwent multiple procedures $(2,11,15)$.

The ceramics of hydroxyapatite has been studied because it is a non-toxic bioactive substance that causes few tissue reactions, being thus an important resource for bone replacement ${ }^{(13,15)}$. It has been employed in a variety of areas, including bone de-
Trabalho realizado no Departamento de Biomecânica, Medicina e Reabilitação do Aparelho Locomotor da Faculdade de Medicina e Ribeirão Preto-USP. Trabalho realizado com auxílio do CNPQ

1 - Pós Graduanda do Departamento de Biomecânica, Medicina e Reabilitação do Aparelho Locomotor.

2 - Médica do Departamento de Clínica Médica do Hospital das Clínicas. 3 - Pós Graduando Departamento de Biomecânica, Medicina e Reabilitação do Aparelho Locomotor.

4 - Professor Associado do Departamento de Biomecânica, Medicina e Reabilitação do Aparelho Locomotor.

Endereço para correspondência: Av. Bandeirantes, 3900 - Hospital das Clinicas de Ribeirão Preto - $11^{\circ}$ andar - Campus Universitário - 14048-900 - Ribeirão Preto/SP e-mail: hladefin@fmrp.usp.br
Work performed at the Department of Biomechanics, Medicine and Rehabilitation of the Locomotor Apparatus, Faculty of Medicine, University of Sao Paulo, Ribeirao Preto, SP, Brazil

1 - Post-grad student, Department of Biomechanics, Medicine and Rehabilitation of the Locomotor Apparatus.

2 - Doctor, Department of Medical Clinic, Hospital das Clínicas.

3 - Post-grad student, Department of Biomechanics, Medicine and Rehabilitation of the Locomotor Apparatus.

4 - Associate Professor, Department of Biomechanics, Medicine and Rehabilitation of the Locomotor Apparatus.

Address: Hospital das Clinicas de Ribeirao Preto - $11^{\circ}$ andar - Campus Universitário - Av. Bandeirantes, 3900 - Ribeirao Preto, SP 14048-900 - Brasil

e-mail: hladefin@fmrp.usp.br 
reação tecidual, apresentando-se como um importante recurso para a substituição óssea ${ }^{(13,15)}$. Seu emprego tem sido muito diversificado, tendo sido utilizada para o preenchimento de faIhas ósseas e reconstrução de defeitos ósseos provocado por ressecções cirúrgicas; revestimento de componentes metálicos para fixação ou no revestimento da superfície de metais ${ }^{(2,5,8)}$

A hidroxiapatita tem sido objeto de nosso estudo, e esse trabalho teve como principal objetivo a avaliação experimental da integração óssea da hidroxiapatita, considerando-se a utilização de grânulos de diferentes dimensões desse material, com a finalidade de observar a possível influência do tamanho dos grânulos de hidroxiapatita na velocidade e qualidade do processo de integração óssea

\section{MATERIAL E MÉTODOS}

\section{Material}

Foram utilizados 55 ratos machos da raça Wistar, com peso variando de 200 a 300g, fornecidos pelo Biotério Central da Faculdade de Medicina de Ribeirão Preto.

A hidroxiapatita utilizada para o estudo foi a GEN-PHOS* granulada, que é uma hidroxiapatita sintética não reabsorvível, tendo sido utilizado três diferentes tipos dessa hidroxiapatita com relação ao tamanho dos seus grânulos, as quais denominamos: Tipo I $(0.212 \mu)$, Tipo II $(0.500 \mu)$ e Tipo III $(1.00 \mu)$. (Figura 1)

\section{Métodos}

A região ântero-lateral do fêmur direito e esquerdo dos ratos foi utilizada para o estudo. Após a exposição cirúrgica dos fêmures, era confeccionada uma canaleta óssea medindo $5 \mathrm{~mm}$ de comprimento e $2 \mathrm{~mm}$ de largura que era preenchida com hidroxiapatita. No grupo controle, a falha óssea era realizada do mesmo modo e não era preenchida com a hidroxiapatita. (Figura 2)

Os animais foram operados no setor de Medicina Experimental do Hospital das Clínicas da Faculdade de Medicina de Ribeirão Preto, e anestesiados com Nembutal *(5) na dose de 33 $\mathrm{mg} / \mathrm{Kg}$, por meio de injeção intra-peritoneal. Após a anestesia, era realizada a tricotomia, assepsia e antissepsia dos membros inferiores com PVPI degermante * e álcool iodado.

Os fêmures eram abordados por meio de incisão longitutinal de cerca de $2 \mathrm{~cm}$ na face lateral das coxas, tendo sido produzida uma falha óssea de $5 \mathrm{~mm}$ de comprimento e $2 \mathrm{~mm}$ de largura, que estendia até a medula óssea.

A falha óssea era completamente preenchida com a hidroxiapatita, e o tipo de hidroxiapatita utilizada dependia do grupo experimental a que pertenciam os animais.

Após o preenchimento da

fects and reconstruction of bone defects secondary to surgical resections, coating of metal components for fixation, or metal surface coatings ${ }^{(2,5,8)}$.

Hydroxyapatite in bone integration was the object of this study in which different sizes of granules of this material were used with the purpose of observing a possible influence of such sizes on the speed and quality of the bone integration process.

\section{MATERIAL AND METHODS}

\section{Material}

Fifty-five male Wistar rats weighing between 200 and $300 \mathrm{~g}$ were provided to us by the Central Bioterium of the Faculty of Medicine of Ribeirao Preto for this study.

Three types of Granulated GEN-PHOS* (a synthetic hydroxyapatite that is not reabsorbed) were employed according to the size of their granules, that is, Type I $(0.212 \mu \mathrm{m})$, Type II (0.500 $\mu \mathrm{m})$ and Type III (1.00 $\mu \mathrm{m})$ (Figure 1).

\section{Methods}

The anterolateral regions of the rats' right and left femurs were used in the study. After the surgical exposure of the femurs, a 5$\mathrm{mm}$ long and 2-mm wide bone flute was produced and filled up with hydroxyapatite. In the control group, a bone defect was produced in the same manner, but was not filled up with hydroxyapatite (Figure 2).

The animals received an intraperitoneal 33- $\mathrm{mg} / \mathrm{kg}$ dose of anesthetics Nembutal ${ }^{*(5)}$ and were operated at the sector of Experimental Medicine, Hospital das Clínicas, Faculty of Medicine of Ribeirao Preto. After the anesthesia the lower limbs were submitted to trichotomy, asepsis and antisepsis with PVPI degerming * and iodinated alcohol.

All femurs were approached by means of a 2-cm longitudinal incision performed on the side faces of the thighs, and a $5-\mathrm{mm}$ long, 2-mm wide bone defect was performed, which extended up to the bone marrow.

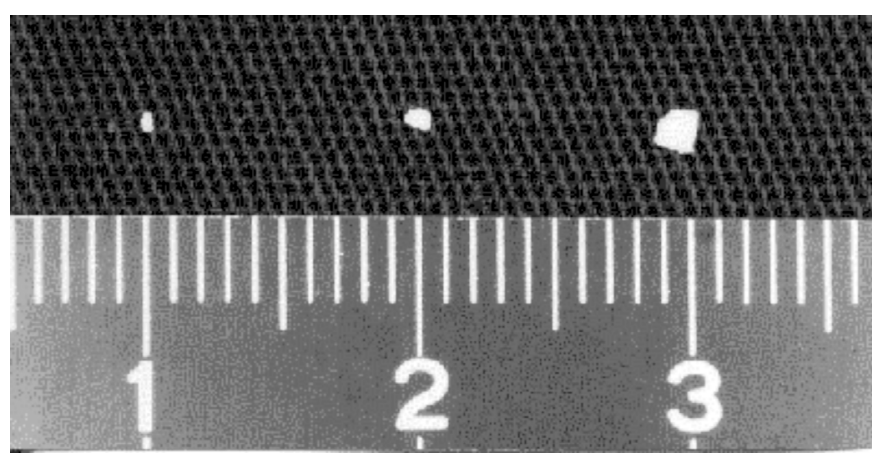

Fig. 1- Fotografia ilustrando as diferentes dimensões dos grânulos de hidroxiapatita utilizada para o preenchimento das falhas ósseas. Da esquerda para a direita estão apresentados respectivamente os grânulos de $211 \mu, 500 \mu$ e $1000 \mu$.

Figure 1 - Illustrating different dimentions of hydroxyapatite granules employed to replace bone defects. From left to right are presented granules of $0.212 \mu \mathrm{m}, 0.500 \mu \mathrm{m}$ and $1000 \mu \mathrm{m}$ respectively
The bone defect was totally filled with hydroxyapatite; the type of hydroxyapatite employed depended on each experimental group of animals.

Once the bone defect was filled, the muscular planes were sutured in blocks with separate stitches using 3/0 Catgut Chromic suture ${ }^{* *(6)}$, while the skin was sutured using Mononylon 4/ 0 thread $* * * *(7)$. During the immediate post-operative period all animals were allowed to walk with no restrictions and each one received 5,000 U of benzyl penicillin potassium intramuscularly $\star * * * *(8)$ during the first 3 days of the post-operative period. 
falha óssea, os planos musculares eram suturados em blocos com pontos separados, utilizando-se fio Catgut Cromado 3-0***(6), e a pele era suturada com fio Mononylon 4-0****(7). No pós operatório imediato todos os animais foram liberados para deambulação sem restrição e receberam $5.000 \mathrm{U}$ intra-muscular de Benzil Penicilina Potássica $* * * \star *(8)$ nos 3 primeiros dias de pós-operatório.

Os animais foram divididos em 3 grupos experimentais, sendo que dois deles eram compostos por 15 animais e um por 25 animais. Os animais foram sacrificados com 30 dias após o procedimento cirúrgico (grupo I), 90 dias (grupo II) e 180 dias (grupo III).

Com objetivo de avaliar-se os diferentes tipos de hidroxiapatita, no mesmo animal, três combinações da aplicação de hidroxiapatita foram realizadas: Tipo I e Tipo II; Tipo II e Tipo III; e Tipo III e Tipo I, tendo sido cada tipo utilizado em um dos fêmures dos animais. Foram utilizados 15 animais para cada tipo de combinação da aplicação da hidroxiapatita, sendo que 5 animais de cada tipo, eram sacrificados com 30 dias de pós operatório, 5 com 90 dias e 5 com 180 dias de pós operatório. (Tabela 1)

O grupo III era composto por 25 animais, sendo que 10 pertenciam ao grupo controle, nos quais a falha óssea não foi preenchida com a hidroxiapatita.

A avaliação da integração da hidroxiapatita com o tecido ósseo foi realizada por meio de estudo histológico com microscopia de luz, e nos animais do grupo III foi também realizado estudo radiológico, utilizando-se filme de mamografia * posicionado a um metro da ampôla do aparelho, com técnica de 38 $\mathrm{Kv}$ e MAS 6.4. As radiografias nos animais do grupo III foram realizadas imediatamente após a cirurgia, com 30, 90 e 180 dias de pós- operatório.

As radiografias foram avaliadas por radiologista do Serviço de Radio Diagnóstico do Hospital das Clínicas da Faculdade
The animals were then divided into 3 experimental groups, of which two included 15 animals and one included 25 animals. The animals in Group I were killed 30 days after the surgical procedure; those in Group II, 90 days after the procedure; and those in Group III, 180 days after the procedure.

Since the objective of the study was to evaluate the different types of hydroxyapatite applied to the same animal, three combinations of hydroxyapatite were used, namely: Type I + Type II; Type II + Type III; and Type III + Type I; each type was used in one of the femurs of each animal. We used 15 animals for each type of combination of hydroxyapatite; 5 animals of each type were killed 30 days after the surgical procedure; five were killed 90 days after the procedure; and another five were killed 180 days after the procedure (Table 1).

Of the 25 animals in Group III, 10 belonged to the control group; therefore, their bone defects were not filled with hydroxyapatite.

The hydroxyapatite integration to the bone tissue was evaluated by a histological study with light microscopy; the animals in Group III were also submitted to radiological investigations, with a mamographic film * positioned 1 meter away from the instrument's vial using the $38 \mathrm{Kv}$ and MAS 6.4. technique. All animals in Group III were X-rayed immediately after the surgery and again 30, 90 and 180 days after the surgery.

The X-rays were evaluated by a radiologist from the Radiodiagnosis Service of the Hospital das Clinicas, Faculty of Medicine of Ribeirao Preto. The parameter used in the radiological study of the bone defects produced was the analysis of presence of bone formation in the defect; such parameter scored 25\%, 50\% and $75 \%$ of bone formation in the defect and complete filling of
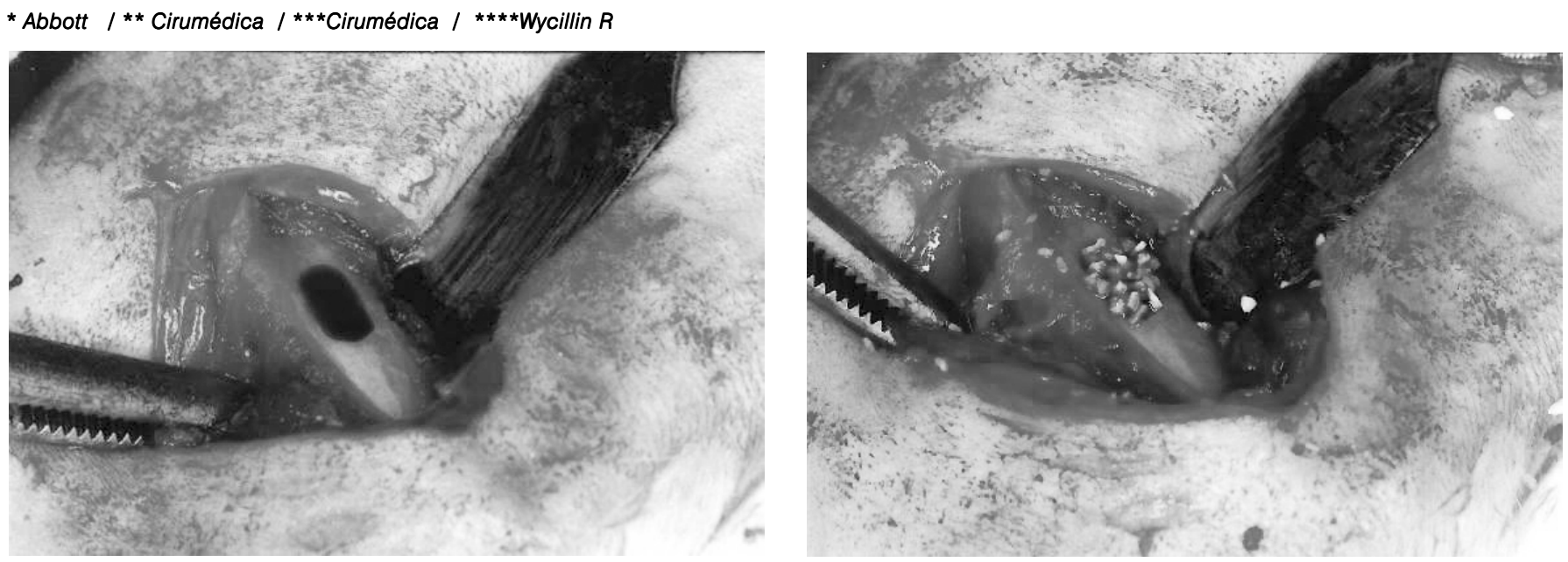

Figura 2 - Fotografias ilustrando a abordagem do fêmur e confecção da falha óssea (A) e o seu preenchimento com a hidroxiapatita (B) Figure 2 - Illustrating femur approaches and a bone defect production $(A)$ and its filling with hydroxyapatite (B) 
de Medicina Ribeirão Preto. Os parâmetros utilizados para a realização do estudo radiológico nas falhas ósseas produzidas consistiram em analisar a presença de formação óssea na faIha, sendo que esse parâmetro foi graduado em 25\%, 50\% e $75 \%$ da formação óssea na falha e completo preenchimento da falha com tecido ósseo. Outro parâmetro analisado nesse estudo foi a verificação do remodelamento ósseo no interior da falha do fêmur, sendo esse parâmetro graduado em ausência de remodelamento na falha, remodelamento do canal medular, remodelamento parcial da cortical e presença de reação periostal.

Com auxílio de um Paquímetro Eletrônico **, as falhas ósseas eram mensuradas nas radiografias ( pós-operatório imediato, 30, 90 e 180 dias de pós operatório), nos maiores eixos das posições ântero-posterior e perfil.

O estudo histológico foi realizado nos três grupos experimentais, de acordo com o período estabelecido para o sacrifício ( 30, 90 e 180 dias de pós operatório). Os fêmures do grupo controle foram submetidos somente ao estudo histológico no período de 180 dias.

Foram realizados cortes histológicos de $6 \mu$ e corados pela técnica da hematoxilina-eosina e Tricrômico de Gomori para o estudo da interface do tecido ósseo e hidroxiapatita.

Os parâmetros utilizados no estudo histológico consistiram na análise da presença de remodelação do defeito produzido no fêmur, que foi graduado em: ausência de união óssea, presença de união fibrosa, presença de união osteocondral e completa reorganização da faIha óssea. Outros parâmetros analisados estavam relacionados ao ao estudo do osso cortical (formação e organização do osso cortical) e do osso esponjoso (atividade celular, formação óssea e reorganização).

As medidas obtidas através da mensuração das falhas ósseas com o uso do paquímetro eletrônico foram submetidas à análise estatística, tendo sido utilizado o teste não paramétrico de Wilcoxom, para comparar mais de dois tratamentos, usando níveis de significância de 5\%.

\section{RESULTADOS}

\section{Avaliação radiológica}

A avaliação radiológica realizada no período pós-operatório imediato mostrou as falhas ósseas preenchidas com a hidroxiapatita, tendo sido possível identifi- the defect with bone tissue. Another parameter analyzed in this study was the checking of bone remodeling inside the femur defect; such parameter was scored as the absence of remodeling in the defect, remodeling of the medullar canal, partial remodeling of the cortical, and presence of periosteal reaction.

The bone defects were measured on the X-rays with the aid of an Electronic Caliper ** (immediate post-operative period and 30, 90 and 180 days after the surgical procedure), along the largest axes of the anteroposterior and profile positions.

A histological investigation was performed in all study groups according to the schedule established for the killings (30, 90 and 180 days after the surgical procedure). The femurs of the control group were submitted only to histological investigation throughout the 180-day study period.

In order to study the bone tissue / hydroxyapatite interface, 6- $\mu$ m thick histological sections were obtained and stained using the hematoxylin-eosin technique and Gomori trichrome stain.

The main parameter used in the histological study was the analysis of presence of remodeling of the defects produced in the femur, which were rated as follows: absence of bone union, presence of fibrous union, presence of osteochondral union, and full reorganization of the bone defect. The other parameters analyzed were related to the cortical bone investigation (formation and organization of the cortical bone) and the spongy bone (cell activity, bone formation and reorganization).

The bone measurements of all bone defects were performed with an electronic caliper and subjected to statistical analysis; the non-parametric Wilcoxon test was employed to compare more than two treatments, using a 5\% significance level. Tipo I (A), Tipo II (B), Tipo III (C) e controle (D). Radiografias com 30 dias de pós-operatório das falhas preenchidas com a H.A Tipo I (E), Tipo II

$(F)$, Tipo III (G) e controle (H), ilustrando a presença de reação periostal nas falhas e inicio do remodelamento do canal medular. Observar inicio de formação do osso cortical $(H)$.

Figure 3 - Pos-operative radiography of bone defects filled up with HA Type I (A), Type II (B),

Type III (C) and control (D). X-rays of bone defects filled up with $\mathrm{HA} 30$ days after surgical procedure Type I (E), Type II (F), Type III (G) and control $(H)$, illustrating the presence of periostal reaction in the defect and initial remodeling of the medullar canal. Notice initial remodeling of cortical bone $(H)$.

\section{RESULTS}

\section{Radiological evaluation}

The radiological evaluation performed during the immediate post-operative period showed that the bone defects were filled up with hydroxyapatite and types of HA employed, while in the control group the bone defects presented well-defined limits (Figure 3) that it was possible to identify the three 
car os três diferentes tipos utilizados, enquanto que no grupo controle a falha óssea apresentava os limites bem precisos. (Figura 3)

Com 30 dias de pós-operatório os diferentes grupos experimentais ainda podiam ser identificados de acordo com o tamanho dos grânulos da hidroxiapatita. O defeito do fêmur já apresentava respectivamente $100 \%$ e $75 \%$ de formação óssea em $60 \%$ e $40 \%$ das falhas ósseas preenchidos com a HA do tipo I. Nos orifícios preenchidos com a HA do tipo II foi observado $75 \%$ de formação óssea em $50 \%$ das falhas ósseas, tendo sido observado $50 \%$ de formação óssea em $50 \%$ das falhas ósseas preenchidas com a HA do tipo III. No grupo controle 100\% de formação óssea foi observado em 40\% das falhas ósseas. O remodelamento do canal medular foi observado em $60 \%$ das falhas ósseas dos fêmures preenchidos com a hidroxiapatita do tipo I, e em $30 \%$ e $20 \%$ nas falhas ósseas preenchidas com a hidroxiapatita dos tipos II e III, respectivamente. O remodelamento completo da cortical foi observado em $20 \%$ dos fêmures preenchidos com a hidroxiapatita tipo I, enquanto que o tipo II apresentou remodelamento parcial da cortical em 50\% dos fêmures e o tipo III em $40 \%$ dos casos. O grupo controle apresentou remodelamento completo da cortical em $60 \%$ dos animais. A reação periostal foi observada em todos grupos experimentais.

Na avaliação radiológica com 90 dias de pós-operatório ainda era possível a diferenciação dos tipos de hidroxiapatita utilizada. A reação periostal ainda estava presente em todos os grupos experimentais. Foi observado o completo preenchi-
Thirty days after the surgical procedure, the different experimental groups could still be identified according to the size of the hydroxyapatite granules. The femur defect already showed $100 \%$ and $75 \%$ of bone formation respectively in $60 \%$ and $40 \%$ of the bone defects filled with Type I HA. Inside the orifices filled with Type // HA, $75 \%$ of bone formation was observed in $50 \%$ of the bone defects, while $50 \%$ of bone formation was observed in $50 \%$ of the bone defects filled with Type III HA. In the control group, $100 \%$ of bone formation was noticed in $40 \%$ of the bone defects. Medullar canal remodeling was observed in $60 \%$ of the bone defects of the femurs that were filled with Type I HA, and in $30 \%$ and $20 \%$ of the bone defects filled with Types II and III HA, respectively. Complete remodeling of the cortical bone was observed in $20 \%$ of the femurs filled with Type I hydroxyapatite, while partial remodeling of the cortical was observed in $50 \%$ of the femurs that were filled with Type II HA and in $40 \%$ of the cases where Type III HA was employed. The control group presented complete remodeling of the cortical bone in $60 \%$ of the animals. Periosteal reaction was observed in all experimental groups.

The radiological evaluation performed 90 days after the surgical procedure still allowed distinguishing the various types of hydroxyapatite employed. Periosteal reaction was still present in all experimental groups. The bone defects have shown to be totally filled in $60 \%$ of the femurs filled with Type I HA, and in $30 \%$ of those filled with Types II and III HA. All bone defects in the control group presented maximum bone formation. Complete remodeling of the cortical was observed in $70 \%$ of the bone defects filled with Type I HA and in $20 \%$ of those filled with Type II
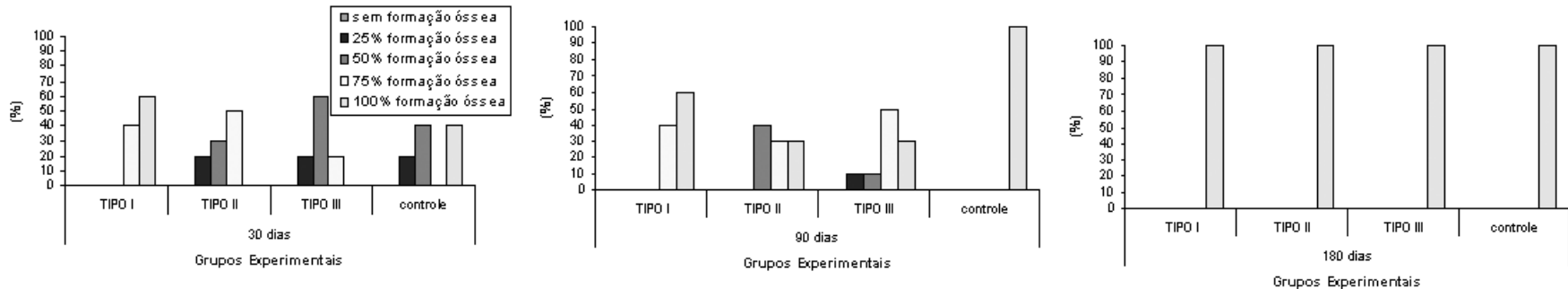

Figura 4. Gráficos ilustrando os resultados radiológicos em relação à formação óssea nas falhas preenchidas com os grânulos de H.A. Tipo I $(0.212 \mu)$, Tipo II $(0.500 \mu)$, Tipo III $(1.00 \mu)$ e controle. A: 30 dias de pós operatório. B: 90 dias de pós-operatório. C: 180 dias de pósoperatório.

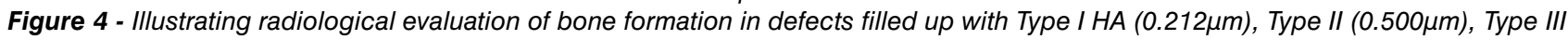
$(1.00 \mu \mathrm{m})$ and control. A: 30 days after surgical procedure. C: 180 after surgical procedure.
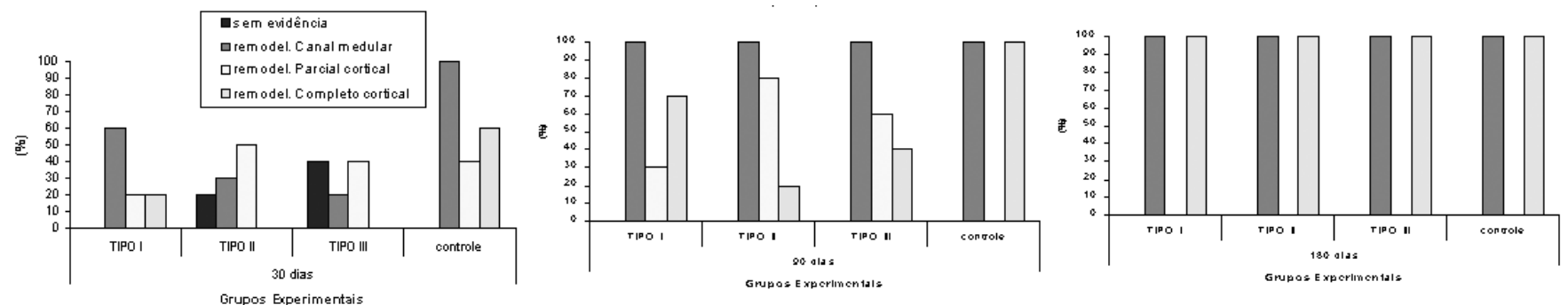

Figura 5- Gráficos demonstrando os resultados radiológicos correspondentes ao remodelamento do canal medular e do osso cortical nas falhas preenchidas com os grânulos de H.A. Tipo I $(0.212 \mu)$, Tipo II $(0.500 \mu)$ e Tipo III $(1.00 \mu)$. A: 30 dias de pós operatório. B: 90 dias de pós-operatório. C: 180 dias de pós-operatório

Figure 5 - Showing radiological evaluation of the remodeling of medullar canal and of the cortical in the defects filled up with Type I $(0.212 \mu \mathrm{m}) \mathrm{HA}$, Type II $(0.500 \mu \mathrm{m}) \mathrm{HA}$ and Type III $(1.00 \mu \mathrm{m})$ HA. A: 30 daya after surgical procedure. B: 90 days after surgical procedure. C:180 days after surgical procedure. 
mento da falha óssea em $60 \%$ dos fêmures preenchidos com a hidroxiapatita do tipo I, em $30 \%$ preenchidos com a HA do tipo II e tipo III. No grupo controle todos as falhas apresentavam a formação óssea máxima. O remodelamento completo da cortical foi observado em $70 \%$ das falhas preenchidas com a HA do tipo I, $20 \%$ do tipo II e $40 \%$ do tipo III, sendo completo em todos os animais do grupo controle.

Na avaliação radiológica com 180 de pós-operatório a identificação dos diferentes tipo de hidroxiapatita não era nítida como nos grupos anteriores. A reação periostal ainda estava presente, porém em menor quantidade. Todos os grupos experimentais, incluindo o grupo controle, apresentavam preenchimento total das falhas ósseas com tecido ósseo e remodelamento completo da cortical em $100 \%$ dos animais.

(Figura 4,5,6 e 7)

O resultado do estudo da mensuração das falhas ósseas nas radiografias, por meio da utilização do paquímetro nos animais do grupo III, mostrou que houve redução do tamanho das falhas ósseas em todos os casos. A redução do tamanho das falhas ósseas foi considerado estatisticamente significativo no período de 180 dias de pós operatório em relação período pós operatório imediato, enquanto que nos outros período do estudo (30 e 90 dias) a redução das falhas não foi estatisticamente significativa (Tabela 2)

\section{Avaliação Histológica}

A avaliação histológica com 30 dias de pós-operatório evidenciou união osteocondral em $80 \%$ das falhas preenchidas com a hidroxiapatita do tipo I
HA and 40\% with Type III HA; complete remodeling was noticed in all animals of the control group.

In the radiological evaluation performed 180 days after the surgical procedure the identification of the different types of hydroxyapatite was not as sharp as in the previous groups. Periosteal reaction was still present, although in smaller amounts. In all experimental groups, including the control group, the bone defects were totally filed with bone tissue and complete cortical remodeling was observed in $100 \%$ of the animals. (Figures 4, 5, 6 and 7).

The bone defects shown in the X-rays as measured by means of a caliper in animals of Group III showed a reduction in size in all cases. This fact was considered statistically significant in the 180-day post-operative period as compared to the immediate post-operative period, while in the other study periods (30 and 90 days) the reduction in the size of defects was not statistically significant (Table 2)

\section{Histological evaluation}

The histological evaluation perfor-

\begin{tabular}{|l|l|}
\hline $\mathrm{T} 1=$ Pós-operatório imediato & $\mathrm{N}=$ Diferença não sigguificativa \\
\hline $\mathrm{T} 2=30$ dias de pós-operatório & $\mathrm{S}=$ Diferenç̧a signifificativa \\
\hline $\mathrm{T} 3=90$ dias de pós-operatório & \\
\hline
\end{tabular}

Tabela 2 - Relação do valor de significância da diminuição das dimensões das falhas produzidas com o tempo de pós-operatório.

Table 2 - Relationship of significance values of decreasing dimensions of bone defects produced as a function of time after surgical procedure. med 30 days after the surgical procedure showed osteochondral union in $80 \%$ of the defects filled with Type I hydroxyapatite and in $90 \%$ of the defects filled with Type /l hydroxyapatite (Figures 8,9 and 10). Reorganization of the spongy bone was observed, with presence of osteoclasts in $30 \%$ of the defects filled with Type I HA and in 10\% of the defects filled with Type /I hydro-
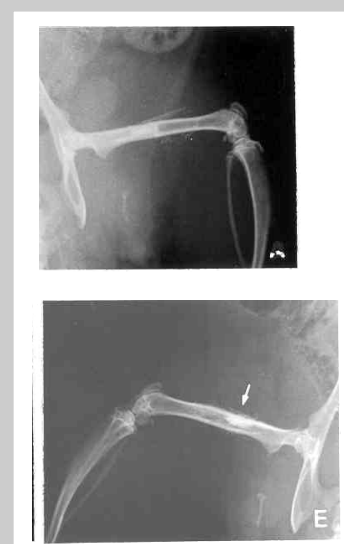
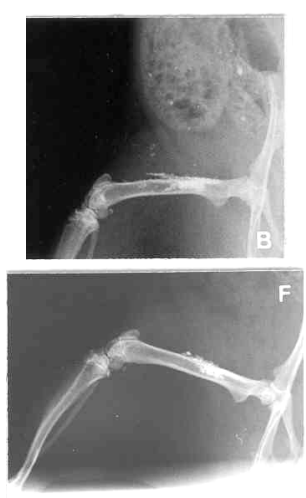
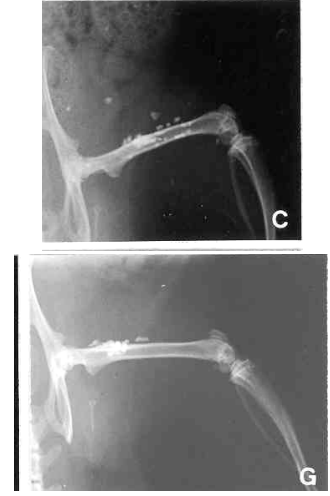

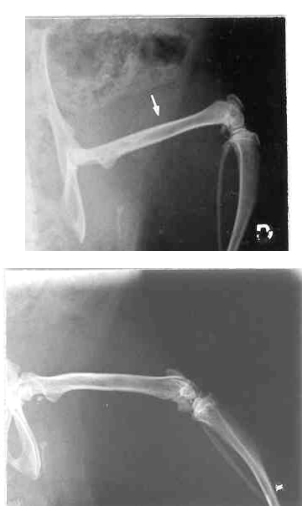

Figura 6 - Radiografias com 90 dias de pós-operatório das falhas ósseas preenchidas com a HÁ do tipo I (A), tipo II (B), tipo III (C) e controle (D). Observar o aumento da reação periostal em relação ao períodos anteriores, e a completa reorganização da falha no grupo controle.

Figure 6 - Radiographies 90 days after surgical procedures of bone defects filled up with Type I HA (A), Type II (B), Type III (C) and control $(D)$. Notice the heightened periosteal reaction compared to former periods, and the complete reorganization of the defect in the control group. radiographies 180 after surgical procedure of the defects filled up with Type I HA (E), Type II Ha (F), Type II HA (G) and control $(H)$. Notice the diminution of periosteal reaction in defects in comparison with 90 days after surgical procedures and the reorganization of bone defect. 
e em $90 \%$ das falhas preenchidas com a hidroxiapatita tipo II (Figura 8,9 e 10). Foi observado reorganização do osso esponjoso com a presença de osteoclastos em $30 \%$ das falhas preenchidas com a hidroxiapatita tipo I e em $10 \%$ nas falhas onde utilizou-se a hidroxiapatita tipo II. O osso cortical estava sendo formado em $90 \%$ dos fêmures preenchidos com a hidroxiapatita tipo I e em $70 \%$ dos casos que utilizou-se o tipo II. Nos fêmures preenchidos com a hidroxiapatita tipo III, foi observado união fibrosa na faIha com início de formação de osso esponjoso e cortical em $50 \%$ dos casos, sendo que o restante não apresentava indícios de união óssea, bem como presença de atividade celular ou início de formação de osso esponjoso ou cortical.(Figura 11,12 e 13)

Com 90 dias de pós-operatório foi observado a união óssea na falha em $90 \%$ dos fêmures preenchidos com grânulos de hidroxiapatita do tipo I e II e união osteocondral em 100\% das falhas que foram preenchidas com hidroxiapatita do tipo III. O osso esponjoso estava completamente organizado em $70 \%$ das falhas preenchidas com as hidroxiapatita tipo I e II e parcialmente organizado em $70 \%$ das falhas preenchidas com a hidroxiapatita do tipo III.

O osso cortical estava parcialmente organizado em $90 \%$ dos casos nos quais foi utilizado o grânulo do tipo I e em $50 \%$ dos fêmures preenchidos com grânulos do tipo I ou II.

Na avaliação com 180 dias de pós-operatório a reorganização da falha óssea foi observada em $100 \%$ dos casos nos quais foi utilizada a hidroxiapatita tipo I e tipo II, e em $80 \%$ dos fêmures preenchidos com a hidroxiapatita do tipo III. Observou-se completa reorganização do osso esponjoso para todas falhas estudadas. A parte cortical estava completamente reorganizada em $70 \%$ dos casos preenchidos com os grânulos do tipo I e tipo II e em $60 \%$ dos casos preenchidos com o tipo III. Os diferentes tipos de grânulos de hidroxiapatita utilizados ainda podiam ser vistos, porém notou-se uma diminuição na quantidade de grânulos de hidroxiapatita do tipo I $(0.212 \mu)$ em relação aos períodos anteriores para o mesmo tipo de hidroxiapatita utilizada.

\section{DISCUSSÃO}

A influência das dimensões dos grânulos de HA na sua integração com o tecido ósseo tem sido relativamente pouco estudada, considerando-se a atenção que tem sido dispensada nos últimos anos ao estudo dos materiais cerâmicos empregados na substituição do tecido ósseo. xyapatite. The cortical bone was being formed in $90 \%$ of the femurs filled with Type I hydroxyapatite and in $70 \%$ of the cases where Type II HA was employed. In the femurs filled with Type III hydroxyapatite, fibrous union was observed in the defect, and the beginning of spongy and cortical bone formation in $50 \%$ of the cases, while the rest showed no evidence of bone union, presence of cell activity or formation of spongy and cortical bone (Figures 11, 12 and 13).

Ninety days after the surgical procedure, the defect presented bone union in $90 \%$ of the femurs filled with granules of Types I and II hydroxyapatite, and osteochondral union in $100 \%$ of the defects filled with Type III hydroxyapatite. The spongy bone showed complete organization in $70 \%$ of the defects filled with Types I and II hydroxyapatite, and partial organization in $70 \%$ of the defects filled with Type III hydroxyapatite.

The cortical bone was partially organized in $90 \%$ of the cases where granules of Type I HA were used, and in $50 \%$ of the femurs filled with granules of Types I or II.

The evaluation performed 180 days after the surgical procedure showed reorganization of the bone defect in $100 \%$ of the cases where Types I and II HA were used, and in $80 \%$ of the femurs filled with Type III hydroxyapatite. In all defects studied, the spongy bone showed to be totally reorganized. The cortical portion was totally reorganized in $70 \%$ of the cases where granules of Types I and II were used, and in 60\% where Type III HA was used. The different types of hydroxyapatite granules employed could still be seen, although a decrease was noticed in the amount of Type I AH granules $(0.212 \mu \mathrm{m})$ as compared to previous periods for the same type of HA employed.

\section{DISCUSSION}

The influence of the size of HA granules on its integration to bone tissue has not been studied in proportion with the attention given during the last few years to the study of ceramic materials employed to replace bone tissues.

The hydroxyapatite employed in our study is a synthetic bioceramic material similar to the one we used in previous studies (3); it was sintered at $1,100{ }^{\circ} \mathrm{C}$ and the size of its pores varies from 1 to $10 \mu \mathrm{m}$. This type of HA is different from natural hydroxyapatite from corals, which are chemically converted through hydrothermal exchanges. 
A hidroxiapatita utilizada em nosso estudo é uma biocerâmica sintética, semelhante a que utilizamos em estudos anteriores $^{(3)}$, sendo essa HA sinterizada a uma temperatura de $1.100^{\circ} \mathrm{C}$, e possuindo poros que variam de 1 a $10 \mu$. Esse tipo de HA difere da hidroxiapatita natural, que é oriunda dos corais, e que são submetidas à uma conversão química por meio de trocas hidrotermais.

Optamos em nosso trabalho, como outros autores ${ }^{(10,12)}$, pela utilização do rato como animal de experimentação, principalmente pela disponibilidade $d$ aquisição desses animais, e pela sua resistência aos procedimentos cirúrgicos realizados. No entanto, apesar do modelo experimental ter sido adequado para
Like other authors ${ }^{(10,12)}$, we chose to use rats in our study as experimental animals, mainly because they are easily available to be acquired, and also due to their resistance to the surgical procedures performed. However, although the experimental model was appropriate to meet the needs of the study, it is worth reminding that the bone marrow of these animals is different from the human spongy bone(3), the same occurring in rabbits used by other authors ${ }^{(9)}$ in trials using $H A$.

We noticed in our study that the three sizes of HA granules employed (212 $\mu \mathrm{m}, 500 \mu \mathrm{m}$ and $1000 \mu \mathrm{m})$ were satisfactory in the sense of filling up the bone defect after six months. However,

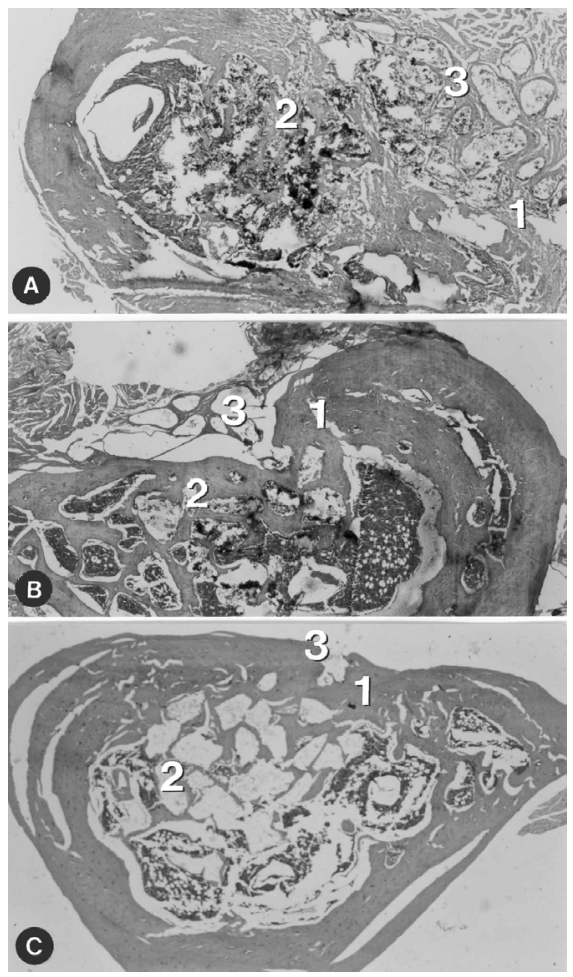

Figura 8 - Fotografias de lâminas histológicas de falhas ósseas de fêmures de ratos, preenchidas com grânulos de hidroxiapatita do tipo I $(212 \mu)$, após $30(A)$, 90 (B) e 180 dias (C) de evolução, evidenciando união óssea (1), osso esponjoso (2) e presença de osso cortical (3) (20x ). Observar presença de grânulos de H.A. na falha $(A)$ e reorganização do osso esponjoso e cortical da falha (C).

Figure 8 - Histological slides of bone defects of femurs of rats filled up with Type I hydroxpyapatite $(0.212 \mu \mathrm{m})$, after $30(\mathrm{~A}), 90$

$(B)$ and 180 days $(C)$ evolution, showing evidence of bone union (1), spongy bone (2) and the presence of cortical bone (3) (20x). Notice the presence of HA granules in the defect $(A)$ and the reorganization of the spongy and the cortical bones of the defect (C).
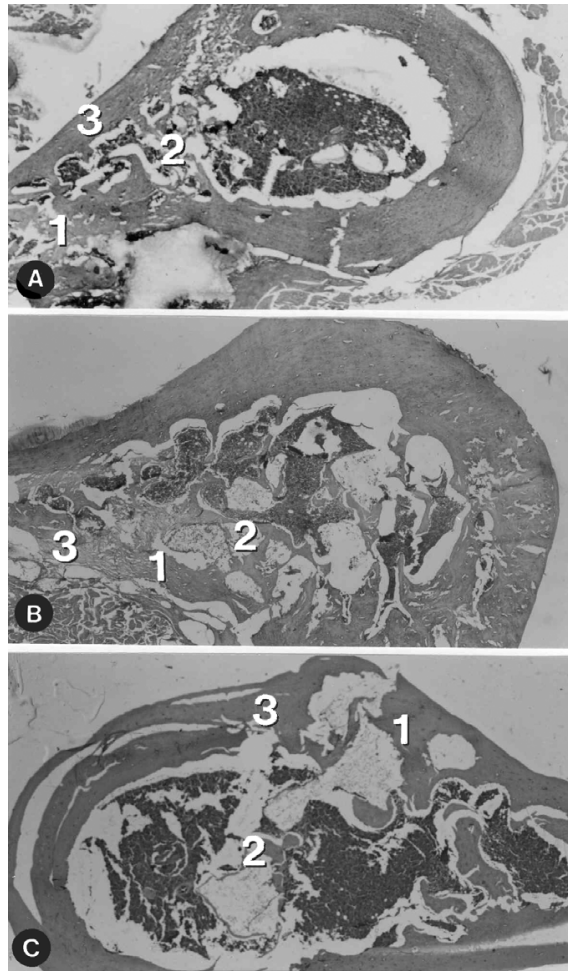

Figura 9 - Fotografias de lâminas histológicas de falhas ósseas de fêmures de ratos, preenchidas com grânulos de hidroxiapatita do tipo II $(500 \mu)$, nos períodos de $30(A), 90$ (B) e 180 dias (C) de pós operatório,

demonstrando o tipo de união óssea na falha

(1), formação de osso esponjoso (2) e reorganização de osso cortical (3)

(20x). Observar reorganização da falha óssea (C).

Figure 9 - Histological slides of the bone defect of femurs of rats filled up with hydroxyapatite granules Type II $(0.500 \mu \mathrm{m})$, in periods of $30(\mathrm{a}), 90$ (B) and 180 (C) days after the surgical procedure, showing the kind of bone union in the defect (1), the formation of spongy bone (2) and the reorganization of the cortical bone (3) (20x). notice the reorganiztion of the bone defect $(C)$.

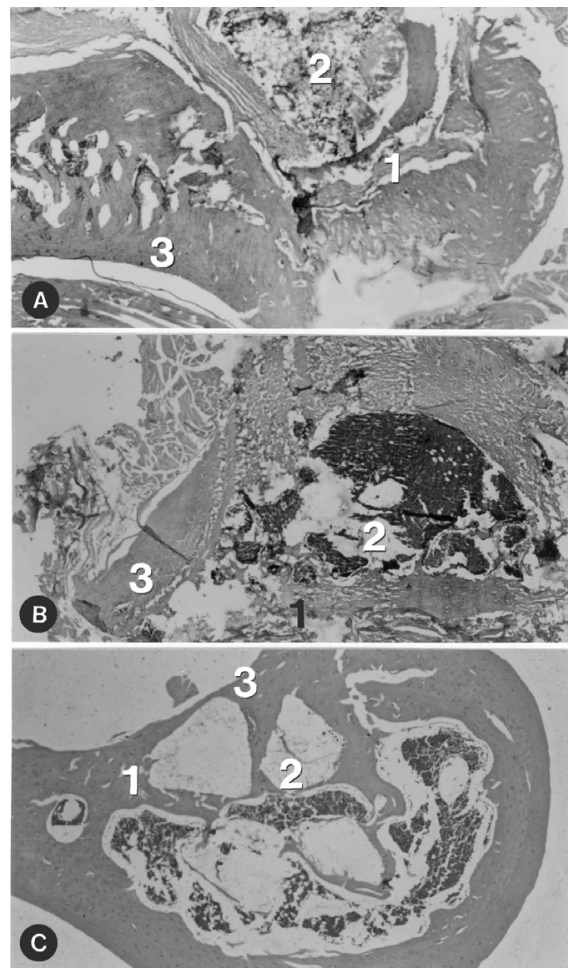

Figura 10 - Fotografias de lâminas histológicas de falhas ósseas de fêmures de ratos, preenchidas com grânulos de

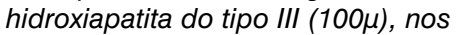
períodos de 30 (A), 90 (B) e 180 dias (C) de pós-operatório, a presença de união óssea (1), reorganização de osso esponjoso (2) e formação de osso cortical (3) (20x). Observar união fibrosa (1A), união osteocondral (1B) e completa reorganização da falha (C).

Figure10 - Histological slides of bone defects of femurs of rats filled up with hydroxyapatite granules Type III $(100 \mu \mathrm{m})$, in periods of 30 (A), 90 (B) and 180 (C) days after surgical procedure, the presence of bone union (1), reorganization of the spongy bone (2) and the formation of cortical bone (3) (20x). Notice the fibrous union (1A), the osteochondral union (1B) and the complete reorganization of the defect $(C)$. 
atender às necessidades do estudo, deve ser lembrado o fato de que a medula óssea do animal utilizado difere do osso esponjoso humano(3), assim como ocorre nos coelhos, os quais foram utilizados por outros autores ${ }^{(9)}$ em estudos experimentais com HA.

Observamos em nosso estudo que as três dimensões de grânulos de HA utilizados $(212 \mu, 500 \mu$ e $1000 \mu)$ foram satisfatória para que ocorresse o total preenchimento da falha óssea após seis meses. No entanto, observamos que o preenchimento da falha óssea ocorreu em menor período de tempo com a utilização dos grânulos menores $(212 \mu)$. Kurada ${ }^{(9)}$ em estudo experimental em coelhos e utilizando grânulos de HA variando de 300 a $2000 \mu$, observou também maior neoformação óssea nas falhas ósseas preenchidas com os grânulos de menor tamanho.

Shapoff et al. ${ }^{(14)}$ consideram que as partículas com tamanho entre 100 a $300 \mu$ apresentam reabsorção mais rápida, maior área de superfície e atuam como material osteocondutor. Esses autores acreditam que a utilização de partículas de menor tamanho impediria a migração e o crescimento intrínseco das células ou vasos sanguíneos, e a conseqüente formação óssea. Ushida et al. ${ }^{(15)}$ observaram também em estudo experimental que as partículas de $300 \mu$ foram as mais apropriadas, tendo sido as partículas menores $(40 \mu)$ observadas ao longo dos prolongamentos dos corpos celulares. Os grânulos com dimensões entre 10 a $50 \mu$ poderiam ser fagocitados por células como os macrófagos ou fibroblastos, devido às suas dimensões reduzidas $^{(10,14)}$. Não foi observado processo de fagocitose em nosso estudo, estando a nossa observação de acordo com os relatos acima mencionados.

$\mathrm{Na}$ avaliação radiológica foi observado que a definição dos grânulos de HA ficava mais discreta e evidente nas falhas ósseas preenchidas com os grânulos menores $(212 \mu)$, estando esse fato provavelmente relacionado com o crescimento intrínseco do tecido ósseo e atividade osteoclástica associada à incorporação da $H A^{(7,11,12)}$

Semelhante às observações de Croci et al.(2) o remodelamento ósseo ocorreu inicialmente no canal medular, seguido pelo remodelamento do osso cortical. Esse fato foi observado em ambos os grupos experimentais, tendo sido observado mais precocemente nas falhas preenchidas com os grânulos menores $(212 \mu)$ e em períodos mais tardios nas falhas preenchidas com grânulos maiores $(1000 \mu)$. No final do seguimento radiológico foi observado uma diminuição, apesar de não ser significativa, dos grânulos de menor tamanho $(212 \mu)$ no interior das falhas. Não tendo sido observado diminuição dos grânulos de maior tamanho no interior das falhas ósseas.

A reação periostal foi observada somente após 30 dias, tornando-se mais intensa no período de 90 dias e menos evidente nas radiografias realizadas com 180 dias após o procedimento cirúrgico. Em estudos anteriores(3) observamos essa reação periostal somente no primeiro mês de pós-operatório e atribuímos a sua presença ao trauma cirúrgico. No entanto, essa explicação para o aparecimento da reação periostal não seria convincente para as observações do estudo atual, permanecendo esse achado sem explicação convincente.

O grupo controle apresentou em todos os animais, completo preenchimento da falha óssea e completo remodelamento do osso cortical durante a avaliação radiológica realizada com we observed that bone defects were filled in a shorter time when smaller $(212 \mu \mathrm{m})$ granules were used. In a trial using rabbits and $300 \mu \mathrm{m}$ to 2,000 $\mu \mathrm{m}$ HA granules, Kurada ${ }^{(9)}$ also observed a higher formation of new bone in bone defects filled with smaller granules.

Shapoff et al(14) believe that particles whose sizes vary from 100 to $300 \mu \mathrm{m}$ show faster resorption, their surface area is larger and they act as an osteoconductive material. These authors believe that the use of smaller particles would prevent cells or blood vessels from migrating and intrinsically growing, with consequent bone formation. Ushida et al(15) also observed in a trial that particles measuring $300 \mu \mathrm{m}$ were the most appropriate and that smaller particles $(40 \mu \mathrm{m})$ were observed along the extensions of cell bodies. The $10-50 \mu m$ granules might be phagocytized by cells such as macrophages and fibroblasts due to their small size $^{(10,14)}$. No phagocytosis process was observed during our stu$d y$, which is consistent with the above-mentioned reports.

It was observed in the radiological evaluation that the definition of HA granules would become more discreet and evident in bone defects filled with smaller $(212 \mu \mathrm{m})$ granules and most likely this fact was related to the intrinsic growth of bone tissue and the osteoclastic activity associated with HA incorporation ${ }^{(7,11,12)}$

Similarly to the findings by Croci et al ${ }^{(2)}$, bone remodeling occurred originally in the medullar canal, followed by cortical bone remodeling. This fact was seen in both test groups, although it was seen earlier in bone defects filled with smaller granules (212 $\mu \mathrm{m})$ and in later periods in bone defects filled with larger granules $(1000 \mu \mathrm{m})$. At the end of the radiological monitoring, a decrease in the smaller granules inside the defects was observed (212 $\mu \mathrm{m})$, although non-significant, and no significant decreases in the larger granules was observed inside the bone defects.

Periosteal reaction was observed only after 30 days, which became more intense within 90 days and less evident in the $X$ rays made 180 days after the surgical procedure. In previous studies ${ }^{(3)}$ we observed such periosteal reaction only during the first month after the surgical procedure and associated its presence to surgical trauma. However, this explanation for the appearance of periosteal reaction would not be convincing as regards the observations made in this study, so this finding still lacks a proper explanation.

All animals in the control group presented bone defects totally filled and a complete remodeling of cortical bone during the radiological evaluation performed 90 days after the surgical procedure. Also, it was noticed that in HA-filled bone defects the growth of newly formed bone tissue has occurred later as compared with the control group. Such findings might be related to the small dimensions of the bone defect $(5 \mathrm{~mm})$, although the production of larger defects would place the bone structure at risk, since it might be fractured, preventing the study to be completed.

Considering the above-mentioned restrictions imposed by the experimental model, it was possible to observe that the hydroxyapatite employed in our study was biocompatible, allowing the bone defect to be repaired, although in a larger period as compared with the control group; also, the bone defect repair has 

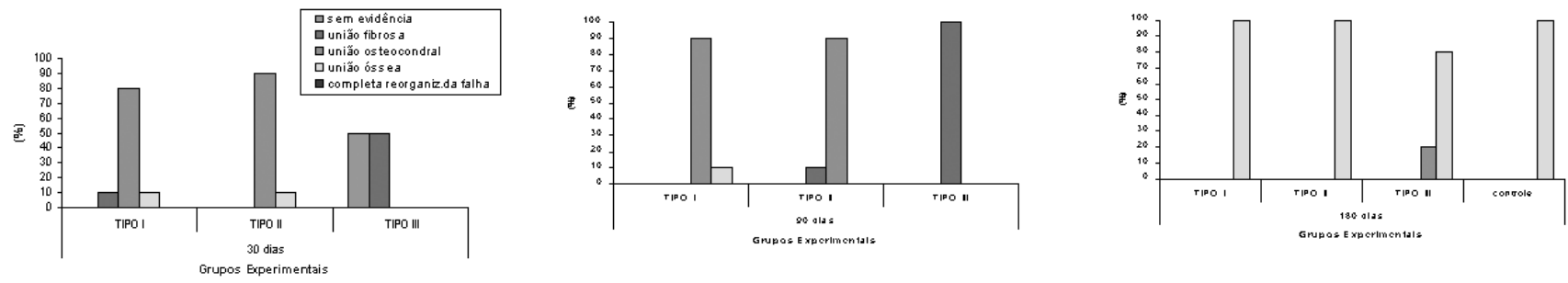

Figura 11 - Gráficos ilustrando os resultados da avaliação histológica em relação ao tipo de união óssea nas falhas preenchidas com os grânulos de H.A. do Tipo I $(0.212 \mu)$, tipo II ( $0.500 \mu)$ e Tipo III( $1.00 \mu)$ e o controle, após 30 (A), 90 (B) e 180 (C) do procedimento cirúrgico.

Figure 11 - Illustrating the results of the histological evaluation of the kind of bone union of the defects filled up with HA granules Type I $(a .212 \mu \mathrm{m})$, Type II $(0.500 \mu \mathrm{m})$ and Type III $(1.00 \mu \mathrm{m})$ and the control, $30(A), 90(B)$ and $180(C)$ days after surgical procedure.
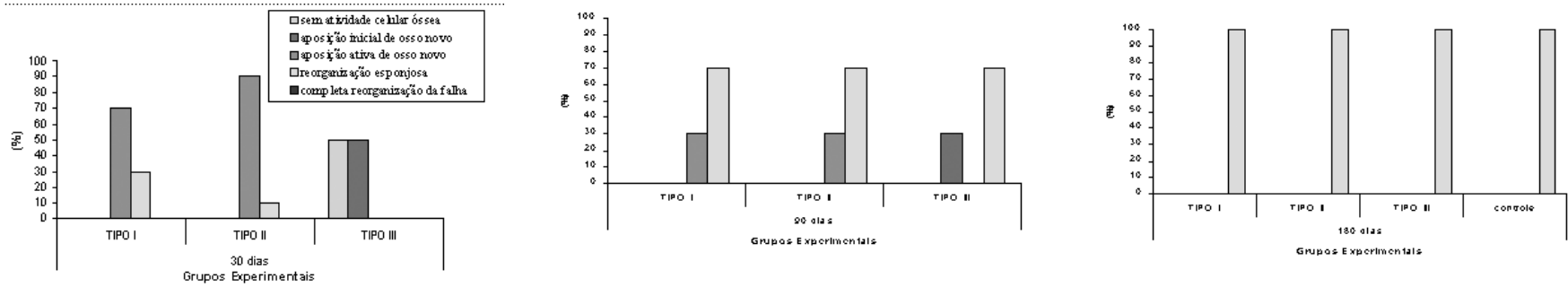

Figura 12- Gráficos ilustrando os resultados da avaliação histológica relacionada com a reorganização esponjosa nas falha

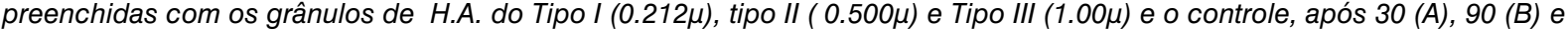
180 dias (C) do procedimento cirúrgico.

Figure12 - Illustrating the results of histological evaluation of the spongy reorganization of defects filled up with HA granules Type I $(0.212 \mu \mathrm{m})$, Type II $(0.500 \mu \mathrm{m})$ and Type III $(1.00 \mu \mathrm{m})$ and the control, $30(\mathrm{~A}), 90(B)$ and $180(\mathrm{C})$ days after surgical procedure.
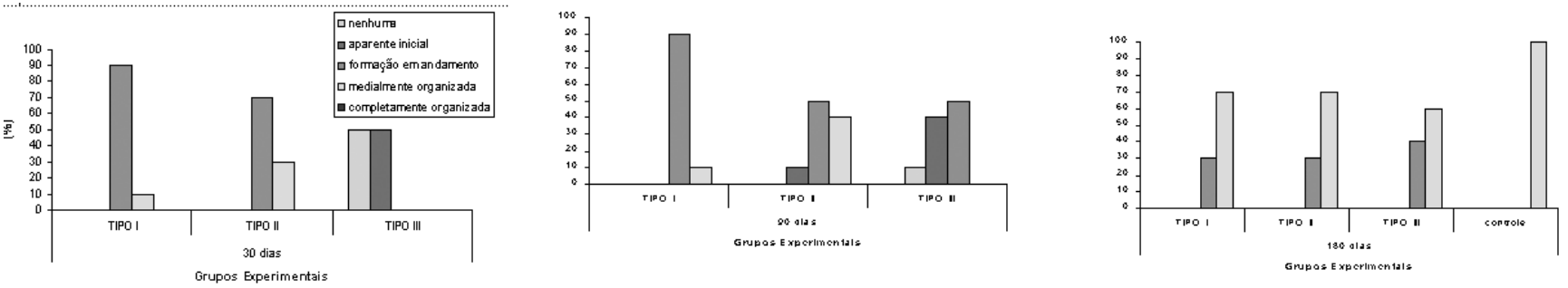

Figura 13 - Gráficos ilustrando os resultados da avaliação histológica relacionada com a reorganização do osso cortical nas falhas

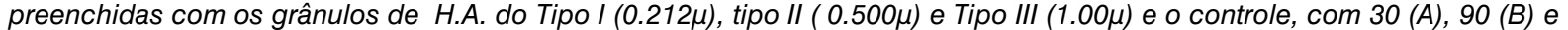
180 dias $(C)$ após o procedimento cirúrgico.

Figure 13 - Illustrating the results of the histological evaluation of the reorganization of the cortical bone in the defects filled up with HA granules Type I $(0.212 \mu \mathrm{m})$, Type II $(0.500 \mu \mathrm{m})$ and Type III $(1.00 \mu \mathrm{m})$ and the control, $30(\mathrm{~A}), 90$ (B) and 180 (C) days after surgical procedure. 
90 dias de pós-operatório. Foi também observado que nas faIhas ósseas preenchidas com a HA o crescimento do tecido ósseo neoformado ocorreu mais tardiamente, quando comparado com o grupo controle. Esses achados poderiam estar relacionados com as pequenas dimensões da falha óssea $(5 \mathrm{~mm})$, mas a realização de falhas de maiores dimensões, colocaria em risco a estrutura do osso, que poderia apresentar fraturas, comprometendo a realização do estudo.

Considerando-se as restrições impostas pelo modelo experimental e que já foram apresentadas, foi possível observar que a hidroxiapatita utilizada no estudo foi biocompatível e permitiu a reparação da falha óssea, ainda que em período maior que o observado no grupo controle, tendo sido observado que a reparação da falha óssea ocorreu em menor período de tempo nas falhas ósseas em que os grânulos de HA de menor dimensão foram utilizados.

\section{CONCLUSÕES}

A hidroxiapatita utilizada no estudo foi biocompatível e permitiu a remodelação da falha óssea produzida no animal. A remodelação da falha óssea ocorreu em menor período de tempo nas falhas ósseas preenchidas com os grânulos de HA de menor tamanho $(212 \mu)$. Nos animais controles em que a falha óssea não foi preenchida com a HA a remodelação da falha óssea ocorreu em menor período de tempo, segundo a avaliação radiológica. occurred in a shorter time in the bone defects filled with smaller HA granules.

\section{CONCLUSIONS}

The hydroxyapatite employed in this study was biocompatible, allowing the remodeling of the bone defect produced in the animals. Remodeling in the bone defect occurred in less time in those bone defects filled with smaller $(212 \mu \mathrm{m})$ HA granules. In the control animals whose bone defects were not filled with $\mathrm{HA}$, bone defect remodeling occurred in shorter periods of time, as confirmed by radiological evaluation.

\section{REFERÊNCIAS BIBLIOGRÁFICAS}

1. Bucholz RW, Carlton A, Holmes RE. Hydroxyapatite and tricalcium phosphate bone graft substitutes. Orthop Clin North Am 18:323-324, 1987.

2. Croci AT, Camargo OP, Campos RF, Oliveira NR. Emprego do compósito trifosfato de cálcio e hidroxiapatita na cirurgia de lesões ósseas cavitárias benígnas não agressivas. Rev Bras Ortop 27: 849-852, 1992.

3. Defino HLA, Conti O, Velludo MAS. Estudo experimental da integração óssea da hydroxyapatite. Rev Bras Ortop 33:713-718, 1998.

4. Higashi T, Okamoto $\mathrm{H}$. Influence of particle size of hydroxyapatite as a copping agent on cell proliferation of cultured fibroblasts. J Endod 22:236-239, 1996.

5. Holmes RE, Bucholz RW, Mooney V. Porous hydroxyapatite as a bone-graft substitute in metaphyseal defects. A histometric study. J Bone Joint Surg Am 68: 904-911, 1986.

6. Jarcho M. Calcium phosphate ceramics as hard tissue prosthetics. Clin Orthop 157: 259-278, 1981.

7. Jiancho Z, Xingdong Z, Gross V. The early host and material response of hydroxyapatite/ b - tricalciumphosphate porous ceramics after implantation into the femur of rats. J Mater Sci 5: 243-251, 1994.

8. Klawitter J, Hulbert S. Application of porous ceramics for the attachment of load bearing orthopedic applications. J Biomed. Mater Res 2:161, 1971.
9. Kurada T. Bone formation and mechanical properties of the cancellous bone defect site filled with hydroxyapatite granules. Nippon Seikeigeka Gakkai Zasshi 69:1037- 1049, 1995.

10. Oliveira AT, Granjeiro JM, Maeda L, Chacon M, Fonseca MA, Taga EM, Taga MJL. Hidroxiapatita microgranular: Comportamento biológico em tecido subcutâneo de ratos. Revisão Odontológica UNESP 22:197-202, 1993.

11. Oonish H.. Orthopaedics Applications of hydroxyapatite. Biomaterials 12:171178,1991

12. Redondo LM, Garcia CJM, Verrier HA, Vaquero PC.. Effect of particulate porous H.A. on osteoinduction of demineralized bone autografts in experimental reconstruction of the rat mandibule. Int J Oral Maxillofac Surg 24:445-448, 1995. 13. Rossi JD.MB, Costa RC, Leivas TP. Avaliação Mecânica de compósitos de hidroxiapatita - polimetilmetacrilato. Rev Bras Ortop 28:3, 1993.

14. Shapoff CA, Bowers GM, Levy B, Mellonig JT, Yukna RA. The effects of particle size on the osteogenic activity of composite grafts of allogenic freezedried bone and autogenous marrow. J. Periodontol 51: 625-630, 1980.

15. Uschida A, Araki N, Shinto Y, Yoshikawa H, Kurisaki E, Ono K. The use of calcium hydroxyapatite ceramic in bone human surgery. J Bone Joint Surg Br 72:298-302, 1990

\section{ERRATA}

Na edição "Volume 11 - Número 3" Artigo "Instabilidade ântero-inferior traumática do ombro: procedimento de Bankart em atletas não profissionais" (páginas 150 a 157) os autores corretos são:

1 - Dr. Ubiratan Maia Rodrigues Vasconcelos - Residente do terceiro ano do Serviço de Ortopedia e Traumatologia FAMERP/FUNFARME.

2 - Dr. Adriano Barros de Aguiar Leonardi - Ex-Residente do Serviço de Ortopedia e Traumatologia FAMERP/FUNFARME.

3 - Dr. André Luiz Reis - Professor Responsável pelo Serviço de Ombro e Cotovelo do Serviço de Ortopedia e Traumatologia FAMERP/FUNFARME.

4 - Prof. Dr. Guaracy Carvalho Filho - Professor Doutor Chefe da Disciplina de Ortopedia e Traumatologia FAMERP/FUNFARME.

5 - Prof. Dr. Alceu Gomes Chueire - Professor Doutor Chefe do Departamento de Ortopedia e Traumatologia FAMERP/FUNFARME. 